\title{
ANALYSIS OF ACCOUNTING TREATMENT OF BIOLOGICAL ASSETS OF NUTMEG PLANT ON NUTMEG FARMERS IN TUMALUNTUNG VILLAGE, KAUDITAN SUB-DISTRICT
}

\author{
Merry L. Sael, Harty U.H.L. Koagouw, Jeane. Christine. Lasut, Decire. D. Wagiu \\ Department Of Accounting, Polytechnic of Manado Country \\ DOI: $10.31364 /$ SCIRJ/v8.i9.2020.P0920805 \\ http://dx.doi.org/10.31364/SCIRJ/v8.i9.2020.P0920805
}

\begin{abstract}
The purpose of this research was to determine the accounting treatment of the biological assets of nutmeg on nutmeg farmers in Tumaluntung village, Kauditan Sub-District, North Minahasa District. The method used in this research is a qualitative approach, which is based on phenomena and explored logically, in accordance with scientific principles. The results showed that the accounting treatment of nutmeg farmers began with the recognition of the current biological assets of nutmeg, namely the cate gory of crops that produce, and valued at fair value (market price), for harvested income. In other words, sales are reduced by costs ranging from equipment, maintenance and expenses. Measurement of biological assets, which is measured by the growth of nutmeg trees, as well as the yield of harvest income, compared to the number of trees owned by the farmer, multiplied by the amount produced per tree, and multiplied by the selling price, and the cost is measured by the total cost for harvesting, and the cost of selling it . Disclosure of the value of the biological assets of nutmeg, which is currently owned by farmers, is the fair value, which is valued at the selling price of the nutmeg tree according to its growth. Although currently, farmers have never recorded their biological assets. It can also be disclosed how much the yields and costs are, so that a net yield is obtained. All of this is recorded and known. With this research, it is hoped that farmers can reveal how the accounting treatment has been done by nutmeg farmers in order to make future plans so that the nutmeg farmers do not experience losses.
\end{abstract}

Keywords: Accounting Treatment, Biological Assets of nutmeg plants

\section{INTRODUCTION}

The history of Indonesia, from the colonial period to the present in the agricultural and plantation sectors, has a very important role in shaping the various economic and social realities of society in various parts of Indonesia. In the agricultural sector, nutmeg plantation is one of the leading sectors that is experiencing fairly consistent growth, both in the plantation area and its production. Nutmeg is one of the plantation crops, whose name has been worldwide for a long time. Traders in the plantation sector are eyeing a lot of these plants because of the high demand and high selling value. The main parts that are the target of many nutmeg traders are the seeds and meat of the nutmeg.

In trade, the coat of nutmeg is called mace, or in pharmaceutical terms it is called myristicae arillus or macis. The first harvest is carried out 7 to 9 years after the trees are planted, and reaches maximum production capacity after 25 years. It can reach 20 meters in height, and its age can reach hundreds of years. Before being marketed, the nutmegs are dried in the sun to dry, after being separated from the fulinya. This drying, takes six to eight weeks. Dried nutmeg is the main ingredient for making various dishes, usually this nutmeg will be crushed and formed into a powder. One of the causes of nutmeg to be special is the essential oil, which is contained in the fruit naturally. Indonesia should be proud of being one of the most fertile nutmeg producers on earth. Meanwhile, North Sulawesi is one of the provinces that prioritizes nutmeg plantations. Nutmeg is a biological asset that undergoes growth transformation, which of course requires costs before producing an output for farmers. However, so far, accounting for biological assets has not been recorded. Statement of Financial Accounting Standards 69: Agriculture provides accounting arrangements that include the recognition, measurement and disclosure of agricultural activities. In general, the Statement of Financial Accounting Standards 69 stipulates that biological assets, or agricultural products, are recognized when they meet the same criteria as asset recognition. These assets are measured at initial recognition, and at the end of each financial reporting period, at fair value less costs to sell.

Www.scirj.org

(C) 2020, Scientific Research Journal

http://dx.doi.org/10.31364/SCIRJ/v8.i9.2020.P0920805

This publication is licensed under Creative Commons Attribution CC BY. 
Tumaluntung Village, Kauditan Sub-District, North Minahasa District is one of the nutmeg-producing villages, where most of the people live from farming the nutmeg plant, and even processing nutmeg into food products, namely sweet nutmeg. With the existence of the biological assets of the nutmeg plant, it can affect the lives of nutmeg farmers. However, all this time the nutmeg farmers have not realized that the biological assets of the nutmeg plant are growing. This growth value will affect the income of farmers so that future planning can be even better because the growth of the nutmeg tree can be determined through accounting treatment. But so far, farmers do not know how the accounting is. Based on the above background, the research team formulated the problem "How to take account of the Biological Assets of Nutmeg Plants in Nutmeg Farmers in Tumaluntung Village, Kauditan SubDistrict".

\section{RESEARCH METHODS}

The method used in this research is a qualitative approach, which is based on phenomena, and logically explored in accordance with scientific principles, which can provide an overview of agricultural accounting regarding recognition, measurement, and disclosure of biological assets. According to Yin (1996) the case study method is based on consideration of 3 conditions, namely:

1. This research is to answer the question "how", "why" or "what" contained in the problem formulation.

2. Researchers cannot control, or influence the object of research.

3. This research is focused on contemporary events.

In this research, it requires interaction between the researcher and the object of research to understand the reality that occurs. This research was conducted in Tumaluntung Village, Kauditan Sub-District, North Minahasa District with the object of research, namely the farmers in the village.

\section{DISCUSSION}

\subsection{Tumaluntung Village Profile}

Tumaluntung is an old village whose civilization has been started since ancient times. This is evidenced by the existence of old graves called waruga, and other findings, in the form of carved stones created by the village's ancestors. The word Tumaluntung comes from the word Motalengteng, which is the name of the original village, which means the echo of a waterfall. This Tumaluntung village area extends $11.5 \mathrm{~km}$ from the north at the foot of Mount Klabat, to the south bordering Airmadidi Atas sub-district. From the East it is bordered by Paslaten Village, Kauditan Sub-District $1.8 \mathrm{~km}$, to the West it is bordered by Airmadidi Sub-District. The total area of the village is $\pm 2400 \mathrm{ha}$, and the plantation area is $2200 \mathrm{ha}$. Altitude of the village $\pm 268 \mathrm{~m}$ from sea level. Is a slope area with an average slope of 6 degrees. The temperature is between 21-31 degrees Celsius. The number of farmers in Tumaluntung village is 257 people. With the existing plantation area in Tumaluntung village, which is 2200 ha. Currently, Tumaluntung village is under the administration of the village head, Neltji Rolos, S. Pd.

\subsection{Potential of Tumaluntung Village}

\section{a. Farmer}

Tumaluntung Village is a village at the foot of Mount Klabat, which has a stretch of agricultural land, and plantations which have an area of 2200 ha. Some people use the land for various crops. There are horticultural crops, and for plantations with nutmeg, coconut and cloves. Agricultural products are sold in the market, and plantation products are sold to contractors.

\section{b. Natural tourism}

Tumaluntung village has a waterfall, which can be a potential for natural tourism, although it is currently not maintained. In addition, there are many waruga-waruga in the village and stone remains carved by the village's ancestors.

\section{c. Boarding House}

Tumaluntung Village, the boarding house business has a great opportunity because it is close to, or adjacent to, the Klabat University Campus, where students really need a place to stay. So that the potential for boarding houses is very appropriate.

\section{d. Other Potential Entrepreneurs}

WwW.scirj.org

(C) 2020, Scientific Research Journal

http://dx.doi.org/10.31364/SCIRJ/v8.i9.2020.P0920805

This publication is licensed under Creative Commons Attribution CC BY. 
Tumaluntung Village has established a partnership with the Agua company in Airmadidi. Where is the Corporate Social Responsibility from the company, namely processing livestock manure into biogas. In addition, many small businesses have developed, such as restaurants, food stalls, and so on

\subsection{Accounting Treatment of Biological Assets of Nutmeg Plants in Nutmeg Farmers in Tumaluntung Village, Kauditan Sub-District, North Minahasa District}

\section{Nutmeg plants}

Plantation and agricultural activities in Tumaluntung Village, Kauditan District are besides waiting for the harvest of annual crops, such as nutmeg, coconut, cloves, and others. Farmers plant horticultural crops, side by side with these perennials. The nutmeg plants in Tumaluntung village are over 15 years old and are already producing.

According to Mr. Noldy Pinontoan as one of the nutmeg plant farmers, and also serving as one of the Tumaluntung village officials, said nutmeg is in the farmer's garden, on average it has produced, and is over 15 years old. The garden in Tumaluntung village, apart from nutmeg, also includes other plants, such as coconut and other horticultural plants. Maintenance is only with a lawn mower, or traditionally, namely hoeing the grass that grows between the nutmeg trees. In other words, maintenance is not difficult.

Generally the nutmeg tree begins to bear fruit at the age of 7 years, and at the age of 10 years it has been producing profitably. Nutmeg production will continue to increase, and at the age of 25 , reach its highest production. The nutmeg tree continues to produce until the age of 60-70 years. Nutmegs can be picked (harvested) after they are quite ripe, which is about 6 months, from flowering until signs of ripe nutmeg. Then, the ripe nutmeg begins to split, through the split groove, and the seeds are visible covered with red mace. If the fruit that has begun to divide, is allowed to remain in the trees for 2-3 days, then the division of the fruit becomes perfect (the fruit is halved), and the seeds will fall on the ground. Nutmeg is harvested twice a year. The nutmeg farmers in Tumaluntung village, and the farmers have nutmeg trees with over 10 trees, over 15 years of age, which on average produce at least 20 kilograms per harvest.

The harvested nutmeg consists of nutmeg, and mace is sold to contractors, and also sold in traditional markets. The price of the harvested nutmeg, namely nutmeg is sold at IDR. 60,000 - 90,000 / kilogram, and mace is sold at IDR. 200,000 / kilogram and a ratio of 10 kilograms of nutmeg produces 1 kilogram of mace. If nutmeg is sold in the market, it can be priced at IDR 250 / seed without mace. Most of the nutmeg is just thrown away.

\section{Accounting Treatment of Biological Assets of Nutmeg Plants in Nutmeg Farmers in Tumaluntung Village, Kauditan Sub- District}

\section{a. Biological Asset Recognition}

The Statement of Financial Accounting Standards 69 stipulates that biological assets, or agricultural products, are recognized when they meet several asset recognition criteria. These assets are measured at initial recognition and at the end of each financial reporting period, at fair value less costs to sell. There are two categories of recognition of biological assets for nutmeg, namely those called immature plants and those that produce crops. Immature plants are recognized from the time of planting the nutmeg seedlings to the time when harvesting begins, which requires a period of 7 years, while mature plants are recognized when the biological assets are ready to be harvested. Biological assets that are recognized as current assets, the useful life / biological transformation period is less than or up to 1 year, and which are recognized as non-current assets, if the useful life / period of biological transformation is more than 1 year. During the cultivation process, several transactions occur from planting to harvesting. Farmers will spend budgets that will be recognized as planting and maintenance costs.

Farmer A revealed that in Tumaluntung village some of the nutmeg trees they had were their own planting, while some of the nutmeg trees they had were inheritance given by their parents, so they did not know the planting costs.

The results of interviews with farmers, the current cost of nutmeg cannot be determined because it was obtained from inheritance.

Farmer S said, I forgot when this nutmeg tree was planted. So, the cost calculation, I don't remember anymore.

Up to now, it is recognized that the nutmeg plant biological assets owned by farmers are categorized as crops that produce at fair price (market value). The value of the biological asset of the nutmeg plant grows according to the growth of the nutmeg tree until it is 25 years old. The recognition of harvest income, or sales is recognized when the farmer harvests his palms, and costs are recognized

www.scirj.org

(C) 2020, Scientific Research Journal

http://dx.doi.org/10.31364/SCIRJ/v8.i9.2020.P0920805

This publication is licensed under Creative Commons Attribution CC BY. 
when costs are incurred for maintenance and selling costs. So the recognition of the biological crop of nutmeg, namely the amount of sales proceeds reduced by costs, ranging from equipment, maintenance and sales costs.

Table 3.1 Type of Activity

\begin{tabular}{|c|c|c|c|}
\hline Number & Type of Activity & \multicolumn{2}{|c|}{ Journal Recommendations } \\
\hline 1. & Income / harvest & $\begin{array}{l}\text { Cash } \\
\text { Sales/ Harvest }\end{array}$ & $\begin{array}{r}\mathrm{XXX} \\
\mathrm{XXX} \\
\end{array}$ \\
\hline 2. & $\begin{array}{l}\text { Payment of direct labor salaries (cost of } \\
\text { harvest) }\end{array}$ & $\begin{array}{l}\text { Labor Cost } \\
\text { Cash/ Account Payable }\end{array}$ & $\begin{array}{r}\mathrm{XXX} \\
\mathrm{XXX}\end{array}$ \\
\hline 3. & Payment of transportation costs & $\begin{array}{l}\text { Transport Cost } \\
\text { Cash/ Account Pyable }\end{array}$ & $\begin{array}{r}\mathrm{XXX} \\
\mathrm{XXX} \\
\end{array}$ \\
\hline 4. & Maintenance costs such as cutting grass & $\begin{array}{l}\text { Maintenance Costs } \\
\text { Cash }\end{array}$ & $\begin{array}{r}\mathrm{XXX} \\
\mathrm{XXX} \\
\end{array}$ \\
\hline 5. & Other costs & $\begin{array}{l}\text { Other Costs } \\
\text { Cash }\end{array}$ & $\begin{array}{r}\mathrm{XXX} \\
\mathrm{XXX}\end{array}$ \\
\hline
\end{tabular}

Source: Processed data

\section{b. Biological Asset Measurement}

The measurement of the biological assets of nutmeg for farmers in Tumaluntung village was measured based on its fair value. The fair value of biological assets is the amount that can be sold to others. Then, income is measured from the selling value of the crop, and costs are measured by the total expenditure for the harvest and the cost of selling it.

Farmer J revealed, the measurement of sales results was measured by estimation, the farmer had 10 trees of nutmeg with an average of over 15 years, and the yield was 2 times a year. Each tree produces $20 \mathrm{~kg}$ of nutmeg, is sold at IDR 70,000/ kg, and $2 \mathrm{~kg}$ of mace is sold for IDR 200,000/ kg. So the calculations, namely: Nutmeg = number of trees $\mathrm{x}$ yield per tree $\mathrm{x}$ selling price. Mace $=$ Number of trees $\mathrm{x}$ Yield per tree: $10 \mathrm{~kg} \mathrm{x}$ selling price.

The calculation is estimated income per farmer

\begin{tabular}{|c|c|c|}
\hline Nutmeg $=10 \times 20 \mathrm{~kg} \times 70.000$ & $=\mathrm{IDR}$ & 14.000 .000 \\
\hline Mace $=10 \times 2 \times 200.000$ & & $=\underline{\text { IDR } \quad 4.000 .000}$ \\
\hline Total Sales & & IDR 18.000 .000 \\
\hline Cost calculation & & \\
\hline Direct labor costs at harvest & & \\
\hline 10 trees with labor @ Rp 100.000 & IDR & 1.000 .000 \\
\hline Transportation fee & & IDR $\quad 500.000$ \\
\hline The cost of maintaining 2 grass cuts & & 500.00 \\
\hline Other Costs & & IDR 1.000 .000 \\
\hline Total Cost & & IDR $\mathbf{3 . 0 0 0 . 0 0 0}$ \\
\hline
\end{tabular}

The estimation result from this calculation is the sale of the nutmeg harvest at a price of Rp. $18,000,000$, minus the cost of Rp. 3,000,000, so the farmer gets a profit or yield of 15,000,000 per harvest.

\section{c. Disclosure of Biological Assets}

Disclosure of biological assets for nutmeg, where the nutmeg farmers disclose their financial statements.

www.scirj.org

(C) 2020, Scientific Research Journal

http://dx.doi.org/10.31364/SCIRJ/v8.i9.2020.P0920805

This publication is licensed under Creative Commons Attribution CC BY. 
The farmer discloses the combined gains or losses arising during the period, upon initial recognition of biological assets and agricultural products, and from changes in fair value less costs to sell biological assets. In addition, farmers must provide a description of each biological asset.

The research results show that basically the farmers have never made financial reports, so so far they only calculate the yields they have manually, even the farmers can only estimate the nutmeg yields they harvest, and the costs they incur. So, of course there is no financial report yet. However, the biological assets of the nutmeg plant that are owned by the farmers can be described as follows:

1. The current value of the biological assets of nutmeg owned by farmers is the fair value which is valued at the selling price of the nutmeg tree, which is in accordance with its growth. The bigger the tree, the greater the value, until the nutmeg is 25 years old. Where the nutmeg tree produces a maximum harvest when it is 25 years old.

2. The selling price of the harvest is adjusted to the selling price at harvest time, and the harvest can change.

3. Costs incurred are in accordance with the harvest.

4. Every time the nutmeg farmers harvest they will definitely get a profit from the harvest.

The results of this study illustrate that the biological asset of the nutmeg plant is a growing asset, and can provide additional income, for farmers in Tumaluntung Village, Kauditan Sub-District, North Minahasa District.

\section{CONCLUSION}

Research activities by the Manado State Polytechnic Team of Accounting Department on nutmeg farmers in the Tumaluntung village, Kauditan Sub-District, North Minahasa District regarding the accounting treatment of the biological assets of the nutmeg plant, it can be concluded as follows:

1. The nutmeg farmers do not know about the accounting treatment of the nutmeg plant, which basically never calculates the increase in yield according to the growth of the biological assets of the nutmeg plant. However, every time they harvested, the farmers would have benefited.

2. With the accounting treatment of the biological assets of the nutmeg plant, the future value of income and costs can be analyzed, so that farmers can plan the management of the crops and the costs of the nutmeg farmers.

3. Nutmeg farmers should be equipped with knowledge about the accounting treatment of nutmeg plants, so that they can calculate or analyze the income and expenditure of nutmeg plants.

\section{REFERENCES}

Achmad Ridwan. 2011. Biological Asset Accounting Treatment of PT Perkebunan Nusantara XIV Makassar (Persero). Makassar: Universitas Hasanuddin

Baroroh, N., Yanto, H., Fajarrini, I., \& Agustina, L. (2018). Accounting of Biological Assets in Indonesian Plantation Companies. Paper presented at the International Conference on Economics, Business and Economic Education 2018.

Belkauoi dan Riahi, Ahmed 2004. Accounting Theory. Jakarta : Salemba Empat

.Financial Accounting Standards Board. 2015. Exposure Draft Statement of Financial Accounting Standards No.69 concerning Agriculture: Jakarta

Harahap Sofyan Syafri (2011), 2011 Revised Edition of Accounting Theory.. Jakarta: Rajawali Pers.

Ikatan Akuntan Indonesia. (2015). Financial Accounting Standards. Jakarta: Salemba Empat

Ibrahim. 2015. Qualitative Research Methodology. Bandung: Alfabeta, cv

Ike Farida (2013) Biological Asset Treatment Analysis Based on International Accounting Standards 41 at PT Perkebunan Nusantara VII, Jurnal Akuntansi UKUNESA volume 2 no 1

www.scirj.org

(C) 2020, Scientific Research Journal

http://dx.doi.org/10.31364/SCIRJ/v8.i9.2020.P0920805

This publication is licensed under Creative Commons Attribution CC BY. 
Kieso, D. E., Weygandt, J., and Warfield,T.D. 2011. Intermediate Accounting IFRS Edition. New Jersey. John Wiley \& Sons Inc

Retno Martanti (2019) Accounting For Biological Asset:Data From Indonesia and Malaysia, International Journal of Innovation, Creativity and Change. www ijicc.net volume 6 issue 9, 2019

Yaqin Ahmad Ainul (2017) Biological Asset Accounting Records at Dairy Farm Cooperative Setia Kawan Nongkojajar, Stie Perbanas 